\title{
Images of 'Love' and 'Death' in the Poetry of Jaláluddin Rumi and John Donne
}

\author{
Esmail Zare-Behtash \\ Chabahar Maritime University, Iran \\ E-mail: behtash@cmu.ac.ir
}

Received: 17-09-2016

Published: 01-03-2017
Accepted: 22-11-2016

doi:10.7575/aiac.ijalel.v.6n.2p.97
Advance Access Published: January 2017

URL: http://dx.doi.org/10.7575/aiac.ijalel.v.6n.2p.97

\begin{abstract}
The purpose of this study is to compare the lives and literary careers of two great poets from the East and the West to find common grounds in their lives and writings. In comparing the poetic works of these two great poets, the study will focus on love and death as two major images in the poetry of these two great poets. Jaláluddin Moláná Rumi as he is called in the West, was a Persian poet-philosopher, and John Donne was a metaphysical poet-preacher from England. These two poets wrote much about their ideas with lucidity and wit. Love and death were both of supreme concern for these poets and a preoccupation of their hearts. Nothing is possible in "love" without "death". Life for Donne is love, the love of women in his early life, then of his wife and finally the love of God. Love for Rumi is sweet madness, healing all infirmities and the physician of pride and self-conceit. Death for Donne is nothing but a transitory passage from here to the hereafter and union with God. Death for Rumi is also a wedding; it is a change from one stage to another as a seed planted in the earth dies in one form in order to be born in another. Both believe that we are from Him, and to Him we shall return.
\end{abstract}

Keywords: Rumi, Donne, love, death, metaphysical poetry, Sufism

\section{Introduction}

Rumi bridges the gap between the Islamic world and the West, and his works represent a common ground for discarding the differences between the East and the West while taking steps on the path of God or the Divine. In other words, ways to God do not distinguish racial or cultural differences. After eight hundred years, people from throughout the world still read Rumi, and the year 2007, the eight hundredth anniversary of his birthday was declared "Rumi Year" by UNESCO (M.Fatih Citlak, 2007) to signify the importance of his call to all humans for unity and ignoring the differences- speaking of himself, he states: "I am neither of the west, nor of the east; nor of the land, nor of the sea; ... for I belong to the soul of the Beloved" who is eternal (R. A. Nicholson, 2004).

Rumi, the greatest Persian mystical poet, was a major exponent of Sufi teachings as well as a profound philosopher. According to Talat S. Halman, a Turkish poet and critic, Rumi's two celebrated works, the Mathnavi and the Divan-i Shams, "represent perhaps the world's most resourceful synthesis of poetry and philosophy, embracing the lyric, narrative, epic, didactic, epigrammatic, satiric and elegiac forms"(Halman, 1988). According to Halman, Hegel praised him as one of the greatest poets and most important thinkers in world history. Sir Mohammad Iqbal of Pakistan proclaimed: "Mauláná [our Master, i.e. Rumi] turned the soil into nectar . . . I became drunk on his wine; now I live with his blessed breath". Whenever entered into a meeting, Mahatma Gandhi used to quote a couplet from the story of "Moses and the Shepherd" taken from Rumi's Mathnavi: "To unite that is why we came; / To divide - that is not our aim"(Zare-Behtash, 1994).

\section{The life and literary career of Rumi}

Jaláluddin Mohammad Balkhi, known in Iran as Moláná or Molavi and in the West as Rumi, was born in Balkh of Khorasan, present-day Afghanistan, in September 1207. The term Rumi, which means "the Roman" or "belonging to Rome", refers to his residential area in Anatolia, which belonged to the Byzantine or eastern Roman Empire conquered and ruled by Muslim Turks, at the time called the Seljuqs. Balkh, as a part of the province Khorasan, was one of the centres of Islamic learning. It was a common practice for Islamic scholars to travel to educational centres throughout Islamic countries in search of knowledge and intellectual companionship. Balkh, Bagdad, Syria and Anatolia were such centres. Rumi's father, the author of the Ma'arif [Divine Sciences] was Bahá' Walad, a well-known theologian, preacher, jurist and mystic surnamed Sultan al-olama, meaning Monarch of Scholars. In his book, Bahá' Walad celebrates his firm faith in the Islamic revelation and undertakes an outspoken defence of its spiritual and esoteric teachings as opposed to the blind legalism of so many of his contemporaries (Schimmel, 1993). He was an authority in the exoteric sciences related to the Sharia, or Divine Law, and the esoteric sciences related to the Tariqa, or spiritual Path. Bahá' Walad instructed ordinary Moslems in their religious duties, and he also trained a group of disciples following the path of self-purification and spiritual perfection- in one word, Sufism. Rumi as a child attended his father's lectures.

Around the year 616/1219, Mongols were imminently moving closer to Balkh following the murder of a couple of Mongol merchants by Khárazmshah, the king of Iran. Bahá' Walad, as well as some other scholars and disciples, decided to leave the city 
for good to make a pilgrimage to Mecca due to the brutality of the Mongols. On their way, they met Attár of Nishapur (c. 1110c. 1220), author of the Conference of Birds and The Book of Mysteries. Attár was a great theoretician of Sufism and hagiographer, who had a tremendous influence on Persian poetry and Sufism. Attár gave the boy (that is, Rumi) a copy of his The Book of Mysteries, telling the boy's father, "he [i.e. Rumi] will soon be kindling fire in all the world's lovers of God" (Chittick, 1984). Rumi later said of him, "Attár was the spirit, Sanái [another great poet] his eyes twain, and in time thereafter, came we in train"(Nasr, 2008). Rumi continues in another well-known line, "Attár has traversed the seven cities of Love, but we are still at the turn of a street".

After performing rituals in Mecca, the family moved to Syria, another centre of Islamic civilisation. After a while, they left for Anatolia, Asia Minor. The whole of Rumi's family were mostly welcomed by the Seljuq's king Alaiddin Keyqobad and his learned vizier, Moeniddin Parváne, who both later became Rumi’s disciples. Among the learned scholars of Konya, Rumi's father came to be known as the Monarch of Scholars.

By the time of his father's death in 628/1231, Rumi had already been an undisputed master of jurisprudence, the Quran, Hadith [sayings of the Prophet], logic, philosophy, mathematics and astronomy (Chittick, 1984). He was asked to assume his father's duty as a preacher and jurisprudent. According to Annemarie Schimmel, Rumi took the formal training in Sufism when a highranking disciple of his father, named Burhan-uddin Tirmizi, came to Konya in 629/1232 to work with Rumi on the paths of Sufism. The theoretical aspect of this path is Sufism, while the practical aspect is Dervishhood. Rumi led the theoretical path as a leader in his time and all afterwards. He set a good example of submission and devotion to God through his constant prayers with passion and love with which he inspired millions (Schimmel, 1993). After a few years, Tirmizi noticed that Rumi was already a mature preacher and Sufi. He suggested that there was no need for Konya to host two masters, and thus he left Konya and died in 638/1240. Now was the time for Rumi to occupy the position of a true Master, preaching to the people of Konya. Huge numbers of disciples attended his lectures. As Professor Chittick holds, at this time Rumi had traversed the stations of the Sufi path and realised a direct and immediate vision of God. In his sermons, he discussed the spiritual mysteries but never revealed that he was different from other jurisprudents. The life of this preacher and jurisprudent of Konya continued normally with no poetical yield until an enigmatic figure called Shams al-din of Tabriz (1185-1248), known as Shams (literally meaning Sun), arrived in Konya and set a fire in the body and soul of Rumi- the preacher. At their first meeting as it is narrated, they looked into each other's eyes for a long time before uttering a single word. They kept their companionship for a few months. Rumi's elder son described this meeting by comparing it to the meeting of Moses with Khidr, the prophet from whose companionship Moses benefited greatly(Schimmel, 1993). All scholars agree upon the fact that without Shams there would have been no Rumi- the poet and lyricist. According to Professor Nasr, quoted by Chittick in his The Sufi Path of Love, "it seems that Shams al-Din was a divinely sent spiritual influence which in a sense exteriorized Rumi's inner contemplative states in the form of poetry and set the ocean of his being into motion which resulted in vast waves that transformed the history of Persian literature"(Chittick, 1984). Shams was Rumi's constant companion for one or two years. Some scholars liken Shams toa great ocean, unidentified and kept in a pot. Once he had asked God for a true disciple in order to reveal all the spiritual mysteries he had acquired. Nobody had enjoyed his company as he pushed hard on educational issues. God granted his demand through a call directing him to Konya to find the companionship of Rumi (Dastranji, 1993). This meeting of two great mature mystics was very important and influential. Feeling that he and Rumi were in danger in Konya, Shams suddenly disappeared. Rumi's meeting with Shams had changed Rumi from an outwardly sober jurisprudent to an inwardly intoxicated celebrant of the mysteries of Divine love.

Rumi had fully devoted himself to Shams and his teachings. Rumi's disciples were not happy with Shams's presence in Konya, as they had lost their master's presence and teachings. In his great book of Divan-e Shams (collected poems under the name of Shams with about forty thousand couplets), which is the "spontaneous overflow" of emotion raised from his acquaintance with and separation from Shams, Rumi in Schimmel's translation (1993: 24) says:

My hand always held a Quran, but now it holds love's flagon;

My mouth was filled with glorification, but now it recites only poetry and song;

Passion for that beloved took me away from erudition and reciting the Quran,

Until I became as insane and obsessed as I am.

Love came into mosque and said, "Oh great teacher!

Rend the shackles of existence; why tied to prayer mat?"

Using poetry, Rumi tried to provide a philosophical framework for his individual transformation into a holy mystic. Love became a fire killing those in its domain, "I got burnt and burnt and burnt ..." Under the name or pretext of Shams, Rumi managed to reveal the mysteries of his union with God:

Indeed Shams-i Tabrizi is but a pretext -

It is I who display the beauty of God's Gentleness.(Chittick, 1984)

Thus, Rumi's poetical works became a display of God's grandeur.

\section{The life and literary career of John Donne}

Compared with the great preacher-poet of Persian literature is John Donne, the great poet-preacher of English literature. Both are considered to be great mystics of two great cultures and both are the product of social crisis. To understand one well, one needs to know the other. Rumi entered the world when the East was suffering from the brutalities of the Mongols, and Donne entered the world when both England and France were suffering from theological and political unrest. It was a time when the Church of England was trying to establish its own identity under Edward VI (1547-53), but under Mary (1553-58) a break happened when 
she forced the Church to turn back to Roman Catholicism. During her reign, about 300 Protestants were burned at the stakeincluding Cranmer, the Archbishop of Canterbury, who was the leading writer of Book of Common Prayer (Willmott, 2002). During the reign of Queen Elizabeth (1558-1603), religion and politics were closely linked, and she tried to bring back and maintain religious tolerance to the country. Since in the Great Chain of Being God was considered to be a higher authority than the Queen or King, people were obliged to recognise that they were being ruled by Divine authority. Though educated a Roman Catholic by his prosperous parents, Donne became a protestant and enjoyed the life of both Elizabethan London and government service for some time. By his secret marriage to Anne Moore, a niece of his patron's wife, he angered the patron, who had Donne imprisoned. This brought his fortunes to the lowest possible level. During these years of obscurity, Donne moved toward service in the Church.

Donne led an extremely varied life, ranging from soldier to courtier, from diplomat to clergyman. Jonathan F.S. Post narrates Donne's life in four phases. (F.S.Post, 2006). The first phase starts from 1572, when Donne was born to a wealthy and committed Roman Catholic family. Through his mother, Donne was related to Sir Thomas More, who had been executed because of refusing to confirm Henry VIII as head of the Church of England. It ends in 1591 when he settles in London after studying at home and university in search of a career. He was educated at both Oxford and Cambridge but could not take a degree due to his Catholic scruples. The second phase begins in 1591 and continues into 1602, coinciding with the final years of unrest of Elizabeth's rule when matters of succession became prominent. For some time he also studied law, but his father's death left him with a considerable inheritance. As a young, handsome, worldly and cynical man, he wrote rough love lyrics which won him some admirers. He never published these poems as an ecclesiastic until after his death, when the world learned of his extensive genius. He was a great visitor of ladies and a great frequenter of plays. His poems range from erotic love poems, frequently of a highly sensual nature, to remarkably powerful religious poems. The third phase starts with his wife at hand and children on the way, searching for some means of income until January 23, 1615, when he would be ordained a deacon and priest. Due to his vast knowledge of the laws of church and state, he was appointed Royal Chaplain later in 1615. Donne's eventual decision raises doubts among his critics (Carey, 1990). The forty-two-year-old Donne required some time for spiritual progress. Jack Donne, the young rake, needed time to become Dr. John Donne, the grave and religious dean of Saint Paul's. The last phase of Donne's life can be summarised as those activities concerned in divinity. He achieved great success as a preacher of sermons, and, like Rumi's audience, people tried not to miss his sermons (Zare-Behtash, 2012).

Donne took his ministerial duties very seriously. He wrote and preached sermons that established him as one of the greatest of preachers in an age of great pulpit oratory - at one point, as Post writes, vowing that "I might die in the pulpit; if not that , yet that I might take my death in the pulpit, that is, die the sooner by occasion of my former labours" (F.S.Post, 2006). In 1621, he became Dean of St. Paul's, a sombre priest much dedicated to thoughts of death but happy with the rejection of the mistresses of his youth. Like Rumi's last days of his life, Donne's later years witnessed a period of extremely poor health when he wrote Devotions upon Emergent Occasions, a set of religious meditations on his disease. During Lent, 1631, he preached his famous sermon called "Death's Duell" before Charles I a few days before his death and then ordered his monument in the shroud. It is narrated that this shroud survived in the great fires of London in 1666 . When Donne died in 1631, he was popularly famous not as a poet but as a preacher. Donne's reputation as a poet had already faded rapidly and was not fully revived until the $1920 \mathrm{~s}$ when T. S. Eliot discovered him as an amalgamation of passion and intellect that had since his time been lost.

\section{The image of love in Donne}

Donne's poetry contains a wide range of subjects. He wrote cynical poetry about inconstancy like "Go and catch a falling star"; poems about true love, such as "The Good-Morrow"; Neoplatonic lyrics on the mystical union of lovers' souls and bodies, such as "Air and Angels" and "The Ecstasy"; brilliant satires; and hymns and holy sonnets depicting his own spiritual struggles, such as "A Hymn to God the Father" and "Batter my heart, three-person'd God". Love is a major theme in metaphysical poetry, and its conceptions derive mainly from the realms of religion, science and philosophy. Life, for Donne, was love, the love of women in his early life, then the love of his wife, and finally the love of God. For Donne, love was the major concern of his mind and heart and thus the subject of his poetry. He tried to experience and understand love both from theoretical and practical aspects. In the 1590s, Donne wrote most of his love lyrics and erotic verse and some sacred poems. Donne's love poetry includes the Elegies and the Songs and Sonnets, poems marked by an energetic, often bawdy wit and a new explicitness about sexual desire and experience (Guibbory, 2006). These poems were not published during his lifetime; rather, they circulated in manuscripts among his close friends, who were expected to be familiar with Donne's wit, or acuteness of thought, and social references. It is as likely that his love poems were written to impress his male friends in London as to seduce a young lady, and in some cases they are addressed to his wife, such as "A Valediction: forbidding mourning”. Regardless of their audiences, Donne's love poems have made a strong impression both for their scorn of the conventions of Petrarchan poetry and for their direct expression of passion itself. The speaker is almost always male, addressing or talking about his lover in a particular way. For example, the speaker portrays himself as a conqueror and his mistress as territory in "Elegy: To His Mistress Going to Bed" and "The Sun Rising".

In Helen Gardner's major edition of John Donne's love poetry, fourteen poems are printed as Elegies (Gardner, 1977). The term "elegy", unlike its modern usage that refers to poems of lamentation for the dead, in sixteenth- and seventeenth-century usage, it is applied to any reflective poem written in regular metre. Donne's elegies owe their inspiration to the love poems of the Roman poet Ovid (43 BC - AD18). Another tradition of the Renaissance was Petrarchan poetry, so named after the early Italian poet Francesco Petrarch (1304-74), whose poems became a model for English poets. Donne tried to imitate the model of Ovid in his elegies in their wit, sexual frankness, amorality and elegance. Donne wrote these poems when he was young, in his early twenties, when he belonged to the society of Lincoln's Inn, Elizabeth I was the queen of England and Petrarchan poetry was popular. Even these poems were an introduction to a true divine love, as we will see in Rumi's case. Donne's poems did not necessarily arise from his personal experience, though some did. Writing in the first person tends to add immediacy and drama to 
a poem. He seems to act out platonic love, lust and mystical devotion. The theatricality of Donne's poems displays the influence and flourishing of English drama in the Renaissance. Donne's Elegies are dramatic addresses of a man to his mistress (except "Sappho to Philaenis", in which Sappho addresses her absent female lover), suggesting the dominance of man. Donne found the male lover's aggressive pursuit of women a more attractive model than Petrarch's submissive, yearning, endlessly devoted and frustrated lover (Guibbory, 2006).

Donne's Songs and Sonnets express different attitudes toward women and the experience of love. What makes these poems remarkable is first of all their titles. If we consider some of the titles such as "The Flea", "The Canonization", "Air and angels" and "The Relic" without knowing the content of the poems, we might wonder what these poems have to do with love. But if we know the poems, we know that each of these titles expresses the guiding idea or image round which the whole poem turns(Redpath, 1987). As Redpath in his introduction to Donne's Songs and Sonnets holds, it is the powerful polarity of Donne's love impulses that transmutes all these spheres of experience into love poetry. In his introduction, Redpath proposes that there are four things in Donne which make him become the master of his art: (1) a considerable range of knowledge and experience; (2) an intellectual and a perceptive sharpness and accuracy of knowledge and observation; (3) powerful love impulses capable of making this knowledge relevant (4) and finally the poetic ability, emotional and intellectual, to draw these into order and make them well-articulated poems.

The Canonization opens with "For God's sake hold your tongue, and let me love" and then "Alas, alas, who's injur'd by my love?" moving to "Call us what you will, we are made such by love"; "We can dye by it, if not live by love". The unity of the title and the poem, as Redpath argues, depends on the fact that Donne and his mistress are not merely harmless (as the second stanza maintains) but will be saints - and that they will then be prayed to by lovers who wish to achieve passions of a high spiritual order. The speaker of the poem continues to say that their "legend" will be fit for sonnets (well-wrought urns) if not for chronicles, and by these hymns written in their praise by succeeding generations of lovers all men will recognise that they have been 'Canoniz' $d$ for love". Thus, the perfection of their relationship will make them a model for future generations of lovers to imitate:

So, to one neutrall thing both sexes fit,

We dye and rise the same, and prove

Mysterious by this love. (11. 25-27)

For Donne, there is something mysterious about love, something beyond the reach of our understanding. Donne's figurative language makes sexual love sacred, suggesting an experience of transcendence, a taste of the Divine (Guibbory, 2006). The experience of intense and reciprocal erotic love offers spiritual fulfilment and access to the Divine. Guibbory argues that Donne's representation of love as both sexual and spiritual is an erotic reworking of the Catholic understanding that body and souls are inseparably linked in the world, in devotion and in the Sacrament.

Songs and Sonnets generally celebrates love as a supremely fulfilling experience in a different world. The Good-Morrow is organised as a pair of lovers "waking" into a new life together and as the new "world" created by their mutual love, which belongs to the past and the future as well as the present reality of their love. Souls awake as well as the bodies, as if they are called by love away from ordinary life and lust. They were not alive until they loved each other. In being together, they create their own entire world. In the reflection of each lover in the other's eye, two benign hemispheres are contained: "Without sharpe North, without declining West". Thus, their world of love will be exempt from coldness of feeling and dark night ("declining West"). Donne believes that whatever dies or decays is because of a lack of unity. Death is a product of imbalance; the perfect equilibrium of their love for each other is immortal:

Whatever dyes, was not mixt equally

If our two loves be one, or, thou and I

Love so alike, that none doe slacken, none can die. (11.19-21)

Donne concludes that if their two loves are so exactly matched they face no decay, and thus there would be no death of love for them. This notion reminds us of the speaker's argument in "A Valediction: forbidding mourning".

Even if Donne's love poems claim that love endures untouched by time, fear of death haunts his love poems. In "The Relique", probably addressed to Lady Magdalene Herbert, the poet looks ahead to the day when his grave will be broken up and his arm bone, encircled with a bracelet of his beloved's hair, will be taken to the "Bishop" and "King" of the time as relics to be preserved, and all women and some men will adore it.

\section{The image of love in Rumi}

Rumi was in his fifties when he started writing Mathnavi, in six volumes, and each with its own introduction, following the demand of one of his disciples called Chalabi. Some scholars following the view of Jami, another great Persian poet, call Mathnavi a "Persian Quran" or an interpretation of the holy Quran in Persian. He took his material from legends, history, hagiography, folk-tales and proverbs talking about pride, freewill, predestination and love all leading along the path to union with the Divine. Presenting Sufi teachings in the form of tales and anecdotes attracted global attention during the late twentieth century.

Rumi is apoet of love, and the central theme of all his works, like Donne's, is love, or ishq, in Persian. The word ishq is believed to come from a plant's name - ashaqeh - which means "ivy", a plant that climbs up woody plants and by making them dry and dead keeps its life going. Love refers to the strong attraction that draws all creatures back to a union with the Creator. Rumi says:

Never be without Love, or you will be dead; 
Die with Love and remain alive.

If you have not been a lover, count not your life as lived;

On the Day of Reckoning, it [i.e. life without love] will not be counted.(Yarshater, 1988)

Sufism is a religion of direct love, direct inner experience. Some asked Rumi about the meaning of Love and he replied:

Someone asked me, "What is love?" I replied, “Aske not

about these meanings;

When you became like me, then you will know. When HE calls you, you will recite its tales.

Hail to thee, then, O Love, sweet madness;

Thou who healest all our infirmities,

Thou who are the physician of our pride and self-conceit.(Schimmel, 1993)

Hence, love purges man and removes all the impurities of the self dealing with pride and self-conceit, which both are sources of wickedness. Mystics argue about the source of love. Some believe that the love of a lover is because of the beloved, while others argue that the existence of a beloved is because of the lover. But the point is that the beloved exists before the lover. Rumi believes that whether the love is from the lover's side or from the beloved's, finally it will lead us to God. The main point is the shared point which, is love, whether the attraction comes from the beloved's end or the lover's; it does not make much difference. The attraction is mutual. Professor Schimmel quotes a line from Rumi's Mathnavi to show this mutual attraction: "Not only the thirsty seek the water, but the water seeks the thirsty as well" (Schimmel, 1993). This line condenses the whole philosophy of love and longing in Rumi's view. Furthermore, it is also ostensible that the beloved hides her love because expressing one's love toward someone is a confession of the priority of the lover. This is impossible for the beloved, who is at the height of perfection and demand; yet, this is not in contrast with his inner attraction. While the lover and the beloved are apparently separated, this separation is not a break-up. John Donne's "A Valediction Forbidding Mourning" is the best example of this sort of love. Donne suggests that the parting of lovers is analogous to the two legs of a drawing compass which move apart but the circle does not break up provided that the relationship is like pure gold, which becomes thin under the beats but never breaks.

Rumi distinguishes two types of love: one "secular love" and the second "spiritual love". Secular love, or in Donne's wording "dull sublunary lovers' love", refers to the physical love, or the one lingered on eyes, lips and hands, the features which make it stressful when lovers separate. Mystics disparage this love, which is transient, and argue that the true love is a permanent longing with a permanent beating of the heart. If the love cools down after union, this is not a true love, it is desire, and true love has no role in that. In the story of "the King and Handmaiden", narrated in the beginning of the Mathnavi, true love is celebrated. The king falls in love with the handmaiden while on a hunting tour, and he takes her to be his own. Through divine destiny, she falls ill. He asks all the doctors to cure her, as his life is nothing without her and she is the surgeon of all his pains. But the doctors fail to cure her. He turns to religious meditation and implores God from the depth of his heart to cure his beloved. In a dream, he is informed that a divine physician will appear to him the next day. When the physician arrives, the king leads him to the handmaiden. The physician examines her and finds out the secret of her illness, as where there is smoke, there is fire. From her grief he finds out that she is heart-sick, and there is no sickness like heart-sick, which is called love. The physician reveals that she had been in love with a goldsmith in Samarkand before the king took her for himself. The King sends a messenger to Samarkand to fetch the goldsmith. He comes, and the handmaiden feels better. The goldsmith, who is in love with the handmaiden, keeps weakening as the spiritual physician gives him medicine; instead of improving, his state is deteriorates, and the passion of the handmaiden cools down, and finally he dies. The reason for this is the fact that the love of the goldsmith is of the secular or physical realm. In contrast, if we consider the love of Zulaykha for Yusuf (Josef) the Prophet, we discover that for a long time she was after the love of Yusuf, but when she enjoys her union with him, she detests that passion and breaks up with him and enters into the valley of Divine love.

Sufism is a path to this true love. Thus, a Sufi becomes a wayfarer travelling back to the Beloved - that is, God - through the mysteries of the heart. The Beloved, or the Divine, is like the Sun: Its warmth makes the snow melt, the fruits ripen; yet, if it draws nearer, the whole world would be set aflame (Schimmel, 1993). One cannot look at the Sun without veils. Rumi, through his stories with lovely allegories and symbols and images, tries to lead his readers to the feeling of the warmth of the Sun, or the Divine love.

Heart becomes the chamber where lover and Beloved share the ecstasy of union. The Beloved looks into the heart of the lover and ignites it with the spark of remembrance, with the call for the journey (Vaughan-Lee, 2013). This spark becomes a fire or light that burns or lightens the chamber of the lover in order to empty him of everything except love. Through the fire or the light of love, we come to know the essence of love. This fire or light is felt as love and tenderness lit by the lamp of the Divine light to help us on the way to Him. In other words, it becomes the epiphany or manifestation of the Divine nature. The "image of fire" is used one hundred and twenty times in Rumi's poetic works (Nasrollah Emami, 2010).

Nothing is possible in love without death. Vaughan-Lee quotes a saying from the holy Prophet, who says, "Die before you die", which means that before you truly experience the sweetness of union with God, you have to sacrifice your ego. You have to be burnt, consumed by the fire of the Divine in order to empty the cup of yourself from all but divine issues so that you fill it with the wine of His love (Vaughan-Lee, 2013). In this regard, Rumi says, "Rise, disencumbered passion, take up love anew; I have died and become void of my old faith and unbelief'.(R. A. Nicholson, 2004). The only obstacle between us and our Beloved is our "self", which should be burned. 
Rumi's poetry is nothing but an attempt to speak of God's grandeur. Love is a key word in understanding Rumi. Love, even a secular love, which is an introduction to the spiritual one, finally leads the lover to the ultimate Beloved. Love, according to Rumi, "is the ultimate transcendence of Human consciousness analytical and rational, intuitive and holistic, but above all devotional and passionate" (Chittick, 1984).

In the story of "The King and the Handmaiden", Rumi talks about physical and spiritual love. The story, as held in the footnote by Nicolson, signifies an allegory. The king typifies the rational spirit; the handmaiden in love with the goldsmith is the soul enamoured of worldly pleasure; the physician, who by poisoning the goldsmith cures the handmaiden of her passion, is a divinely inspired Saint:

Whether love be from this side or from that,

in the end it leads us Yonder.

Those loves which are for the sake of a colour are not love:

in the end they are a disgrace.

Choose the love of that Living One, who is everlasting and gives thee

to drink of the wine that increases life

Choose the love of Him from whose love all the prophets

gained power and glory.

Do not say, "We have no admission to that king",

Dealings with the generous are not difficult. (R. A. Nicholson, 2004)

To render a serious message, Rumi makes use of ordinary images and every day conversation, like the colloquial language Donne uses in his poems. In a story, quoted by Schimmel, he starts his story with this question: Did you hear? Our neighbour was ill last night? Then he goes on talking about the symptoms of his illness, not giving much information until the reader finds out that the reason for his illness was love. It might seem unavoidable not to use "conceit" in poems dealing with spiritual messages - a technique which Donne becomes master of in English literature. Rumi compares love to a police officer who "enacts fines and confiscation from the whole world". Or a ragman enters the town and shouts to see who has old shoes for sale, who becomes a symbol of love that carries away everything old and rotten. In another story to discern the true faithful from those who are false on the basis of what they say, Rumi, as Schimmel also quotes, takes his audience to the marketplace to test earthen pots. He says if the pots give a good sound, it means they are authentic and worth buying; but those with hidden cracks would sound different, meaning they are fake. This far-fetched comparison to test true love echoes the metaphysical conceits used four centuries later by Donne and his disciples. Rumi's works are replete with this sort of comparison, which rightly proves that talking about spiritual matters requires its own language. Thus for Rumi, everything from his environment or everyday life becomes a symbol for a higher objective.

Rumi has a good sense of humour, too, which is one way of controlling the extremes of emotion. Sometimes in Donne's case the whole poem turns into a conceit that is very humorous, such as "The Flea". In Rumi, even his dirty jokes are instructional. He ridicules people in different situations: like a man looking for cheese on an empty tray or a Sufi who is thrilled by an empty food tray. In short, everything easily becomes a symbol for Rumi, from an animal's excrement to the pleasant breeze of spring. Images related to spiritual alchemy play an important role in Rumi's poetry. The lover is considered to be like base copper that can be transformed to pure gold if the beloved wishes. In a line, as Schimmel quotes, Rumi says: "why do you seek Gold? Make your own copper into gold; and if it is not gold, then come with a silver-breast". For those seeking spiritual growth, alchemy is required to make them pure:

We have melted like copper, thanks to our search for alchemy (i.e. Love);

You, for whom the bed and bedfellow are alchemy, keep sleeping. (p.63)

Thus, Rumi ridicules those who care for sleeping and sensual desires. To receive such a transformation from a base matter to higher quality, one needs to follow the examples or paths of the saints to lead them to the source of perfection or to the Divine:

From myself I am copper, through you: gold;

From myself I am a stone, through you, a pearl. (ibid.)

So without the grace of a saint or the Beloved, it is not possible to attain perfection to become a "perfect man" or, in mystical terms, to become a king. Alchemy is present in Donne, too. In "Love's Alchemy", Donne is cynical about love where any pleasures coming out are like the accidental by-products, and they are not true gold.

\section{The image of death in Rumi}

It is recorded that during the first half of September in 1273, Konya was haunted by frequent earthquakes, and this brought fear to the people of Konya. At this time Rumi was not feeling well, suffering from an illness. Great physicians attended him but failed to cure him. The earth continued shaking off and on. People came to visit their great Master, the Senior of Konya. His disciples asked Rumi to pray for his health, but he refused. He addressed the visitors and said: "The earth is hungry. Soon it will get a fat morsel and then get rest"(Schimmel, 1993). All the visitors were weeping, but Rumi stopped them from weeping saying now that the light is going to connect to the source of light and asking 
why they were so sad. There was a veil which had separated him from the Beloved, and now that the veil was going to drop, why they were not happy, he asked. Rumi wholeheartedly believed that his death was his wedding with eternity, so why not celebrate this union? The following lines in Professor Nicholson's translation (R. A. Nicholson, 2004) are a live testament to Rumi's notion of death:

On the day of death, when my bier is on the move, do not suppose that

I have any pain at leaving this world.

Do not weep for me, say not “Alas, alas!" you will fall into the devil's snare -

that would indeed be alas.

When you see my hearse, say not "parting, parting!" That time there

will be for me union and encounter.

When you commit me to the grave, say not "farewell, farewell!" For,

the grave is a veil over the union of paradise.

What seed ever went down into the earth which did not grow? Why

do you doubt so regarding the human seed?

Thus, death becomes a means of union with the Beloved. Rumi died on Sunday, 17 December 1273 at sunset. People from all walks of life attended his burial. Christians and Jews joined in the funeral prayers. Christians believed that Rumi was their Jesus; for Jews he was their Moses. His disciples had arranged with Rumi for his funeral service to be performed by Sadraddin, the great jurisprudent of the time. Sadraddin attended the ceremony, as he stood in from of the bier of Rumi, people were warned, "mind your manners and be respectful. He was the sultan of the true Sheiks; that is who has passed away". As Sadraddin heard this, feeling so low in front of the bier, he fainted and fell down. So instead, Sirajeddin, another great jurisprudent, led the service (M.Fatih Citlak, 2007). After funeral prayers and music, Sama continued for hours and hours. Rumi's disciples have since then celebrated this evening as shab-i arus, meaning "night of nuptial":

When you come visiting my grave,

My roofed tomb will appear to you dancing;

Do not come without tambourine to my tomb, brother!

For a grieved person does not fit in God's banquet! (Schimmel, 1993)

Following his death, Konya calmed down. Rumi's son, Sultan Walad, founded the Mevlevi Order, known as the Order of the Whirling Dervishes, famous for the Sufi dance known as the Sama ceremony. [It is worth mentioning that Mevlevi is the Turkish pronunciation of Molavi.] The Sama symbolises many aspects of life, such as the creation of the universe, the creation of human beings, our birth and our progress toward God (M.Fatih Citlak, 2007). In the Sama, the palm of one hand is upward, which means receiving from God, and the palm of the other hand faces down, which signifies giving out, meaning generosity from those who have received grace from the Divine.

Professor Cyrus Shamisa, a Persian scholar and lecturer, in his introduction to Gozideh Ghazaliyat-i Shams [A selection of the Lyrics of Shams], discusses Rumi's philosophy in detail. I have tried to summarise and translate part of this introduction as follows:

1) Death does not exist. Death and life are identical. Death is merely a kind of change from one shape to another, just as a seed planted in the earth dies in one form in order to be born as a tree.

2) Death is joining to God, which means eternity. Therefore death is union, and it makes us happy. Thus death is a wedding for lovers.

3) We are but guests in this world with this material body; then we will return to our permanent home. Therefore think about this spiritual and delightful journey and be happy.

4) Everything, animate or inanimate, is a sign of Him. So all creatures can hear, discern and be merry because everything is from Him and carries His attributions and eventually returns to Him. Therefore they praise God's greatness; and nothing happens but by his Will (Zare-Behtash, 1994).

\section{The image of death in John Donne}

As death was a wedding with God for Rumi, death for Donne was a transitory stage between here and the hereafter that everyone will and must endure. It is an end to his suspense and a meeting with the Lord. As a preacher of the Church of England the Bible permeates Donne's universe, providing the fabric and texture of his epistemology, psychology, spirituality and sense of self. (Shami, 2009). John Donne finds "death" challenging, not mournful. For Donne, to think of God is to think of death. His God lives in death's kingdom, and his worship of God entails the worship of death. Death for Donne is nothing but "One short sleep past, we wake eternally, / And death shall be no more; Death thou shalt die" ("Death be no proud", 11. 13-14). This is the same with Rumi, who, in his loving story of "the Merchant and the Parrot", narrates: Once there was a merchant who had a beautiful parrot imprisoned in a cage. When the merchant prepared for a journey to India, he asked his household what to bring back for them. Everybody wished for something. 
The parrot asked him to tell the parrots of India living in the rose gardens about her condition imprisoned in a cage. When the merchant arrived in India, he went to the gardens to deliver the parrot's message. Among those parrots, one parrot trembled, fell and died. The merchant became sorry about telling the story of his parrot to them. After finishing his trading, he returned to his home, bringing a present to each of the household except the parrot. The parrot asked about her present, and the merchant said he was sorry for what happened to her fellow parrot in India when she heard about the story. When the parrot heard about this news, she trembled, fell and died. The merchant blamed his tongue for causing the death of two parrots. The merchant opened the cage and threw the dead parrot out of the cage. The dead parrot made a swift flight. The merchant was bewildered by the bird's action. The merchant asked the bird to reveal the secret, and the parrot replied that her fellow parrot in India, by her action, had advised her to pretend she was dead in order to attain deliverance. And now she was delivered. The moral of the story is that death is just a path by which to pass from this world to the hereafter to meet with the Lord.

Donne's "Death's Duell" was preached before the king at the beginning of Lent not many days before his death. This would be his last sermon, the sermon of a person who is going to die. The language of the sermon is as imaginative and musical as his poetry. It starts with an image of a building with a firm foundation, buttresses and an unarchitectural "knitting" of the materials. These three particulars, like his "Batter my heart Three Person'd God", are compared to the actions of the Persons of the Trinity. God the Father lays the foundation for man's life; he leads us from death into life. The Holy Ghost supports us at the hour of death when we shall enter eternal life, like the buttresses which hold up the building. The God of Mercy, the Son, is like the knitting together of the building and will deliver us by his death from death. Thus, the poem is built around three points: from death, in death and by death - thus, "Unto God the Lord belong the issues of death"(Psalm LXVIII.20).

After death, sleeping souls will rise and return to their bodies to receive judgment. Donne imagines this scene in his holy sonnet IV - "At the round earth's imagin'd corners". The poem opens with the angels at Judgment Day standing at the corners of the earth, and the souls of all who have died - whether of diseases, plagues, floods, famines and of even of old age - will return to their bodies to rise. In the sestet, he addresses God, saying he is not ready for Judgment and needs more time to repent, and the poem ends quietly with the anticipation of God's Grace.

\section{Conclusion}

Rumi, a great Persian preacher-poet, and Donne, a great poet-preacher, each entered the world during a period of unrest and turmoil. Following the invasion of the Mongols in 1219, Rumi's family decided to leave the land and the country for Anatolia, present-day Turkey. Donne entered the world during a period of theological and political unrest for both England and Europe. He was born into a Roman Catholic family and studied at both Oxford and Cambridge universities, but could not obtain his degree due to his Catholic scruples. To follow his ambitions for social promotion, Donne joined the Anglican Church. For both Donne and Rumi, love was the major concern of their minds and hearts, and it became the main subject of their poetry. Both used colloquial language and far-fetched imagery to illuminate their subject. Employing surprising comparisons required sharp intellect, which both possessed. For these great literary and religious figures, love was either physical or spiritual - and both draw all creatures back to union with God. For both, leaving life means experiencing love. These two great figures of the East and the West anticipated their deaths and had already prepared for them. Death for them was union with the Origin of Existence; death was not a punishment but an occurrence everyone will and must endure. It is the passage through which one obtains eternity.

\section{References}

Carey, J. (1990). John Donne: Life, Mind and Art. London: faber and faber.

Chittick, W. (1984). The Sufi Path of Love: The Spiritual teachings of Rumi. New York: State University of New York Press.

F.S.Post, J. (2006). Donne's Life. In A. Guibbory (Ed.), The Cambridge Companion to John Donne (pp. 1-22). Cambridge: Cambridge University Press.

Gardner, H. (1977). The Metaphysical Poets. London: Penguin Books.

Guibbory, A. (2006). Erotic poetry. In A. Guibbory (Ed.), The Cambridge Companion to John Donne (pp. 133-148). Cambridge: Cambridge University Press.

Halman, T. S. (1988). Persian Literature. In E. Yarshater (Ed.). New York: Bibliotheca Persica.

M.Fatih Citlak, H. B. (2007). Rumi and His Sufi Path of Love. New Jersey: The Light, Inc.

Nasr, S. H. (2008). The Garden of Truth. New York: HarperCollins.

Nasrollah Emami, E. A. M. (2010). Fire of Love from Mowlana's View. Research Journal of Persian Language and Literature, 2(5), 1-14.

R. A. Nicholson, A. J. A. (2004). Silent Words: A Selection of Poetry and Prose of Mowlavi. Tehran: Hermes.

Redpath, T. (1987). The Songs and Sonnets of John Donne. Cambridge: Cambridge University Press.

Schimmel, A. (1993). The Triumphal Sun: A Study of the Works of Jalaloddin Rumi. New York: State University of New York Press. 
Shami, J. (2009). John Donne The Blackwell Companion to the Bible in English Literature (pp. 239-252). London: Wiley-Blackwell.

Vaughan-Lee, L. (2013). Love is a Fire: The sufi's Mystical Journey. California: The Golden Sufi Center.

Willmott, R. (2002). Metaphysical Poetry. Cambridge: Cambridge University Press.

Yarshater, E. (1988). Persian Literature. New York: Biliotheca Persica.

Zare-Behtash, E. (1994). FitzGerald's Rubáiyát: A Victorian Invention. (PhD thesis), The Australian National University, Canberra, Australia.

Zare-Behtash, E. (2012). English Metaphysical Poetry in Context. Journal of Lyrical Literature researches, 10(19), 77102. 